\title{
Reforma do setor público e participação sindical: o caso do sistema de pensão italiano ${ }^{1}$
}

\author{
Lucio Baccaro \\ Richard M. Locke
}

\section{Introdução}

Este é um documento sobre o papel dos sindicatos na promoção da reforma do setor público. Boa parte da literatura trata os sindicatos do setor público como organizações rent-seeking, que tentam alcançar ganhos privados às expensas dos benefícios públicos (e do Tesouro Nacional) (LowI, 1969; OLson, 1982). Os sindicatos do setor público têm sido difamados, acusados tanto de bloquear vários esforços de reforma (CHubB e MoE, 1992) quanto de ameaçar a legitimidade de instituições governamentais (McCoNNELL, 1966). Resulta disso que uma reforma bem-sucedida só poderia ocorrer caso os sindicatos fossem evitados ou abolidos (PIERSON, 1994; 1996).

Este documento desenvolve um argumento alternativo. Através do estudo de caso da recente reforma no sistema de pensão italiano, vamos argumentar que os sindicatos podem ter um papel positivo na reforma do setor público. Como em muitos outros países, os sindicatos italianos resistiram durante anos aos esforços de redução de benefícios sociais estatais e de reforma do sistema de aposentadoria. Tais benefícios eram vistos como "direitos adquiridos", produto de uma luta intensa durante as greves do Outono Quente de 1969. Ainda em tempo, a posição dos sindicatos italianos mudou. Mudou por várias razões — não somente pelo óbvio e insuportável custo do sistema vigente - mas principalmente porque eles foram convidados a integrar o processo de reforma. Em outras palavras, ao invés de serem colocados de lado ou derrotados durante a implementação da reforma, os sindicatos italianos foram incluídos nas discussões/decisões relativas ao custo do sistema vigente e das alternativas de reforma propostas.

Baccaro

é estudante de PhD do Departamento de Ciência Política e Locke é professor associado de relações industriais e ciência política do Massachussetts Institute of Technology 
Esse processo de participação não dependia somente das lideranças dos sindicatos. Seus membros ordinários também foram envolvidos no processo de reforma, através de um processo sistemático de consulta. De fato, esse processo foi a chave do esforço da reforma, pois gerou o apoio das fileiras dos sindicatos à reforma e, conseqüentemente, garantiu a capacidade das lideranças dos sindicatos de manterem seu papel de negociação. Em outras palavras, como o processo de reforma foi acompanhado de um extenso processo interno de deliberação, debate e eventualmente, votação, os sindicatos foram capazes de superar a oposição de muitos grupos de trabalhadores e abraçar a reforma. O processo de deliberação e tomada de decisão democrática foi importante não somente porque agregou interesses existentes em torno de uma coalizão pró-reforma, mas também, e talvez o mais importante, porque contribuiu para o delineamento das várias preferências. Discussões e deliberações exaustivas dos sindicatos permitiram que eles mesmos filtrassem as preocupações mais particularísticas e abraçassem posições que acabaram mostrando-se benéficas para o bemestar comum (BACCARO, 1996). Acreditamos que a experiência italiana com a reforma do sistema de pensão fornece lições importantes para o processo de reforma do setor público em outras áreas, e também para outras nações.

O presente documento é dividido em quatro partes. Inicialmente, descrevemos o sistema de pensão italiano altamente fragmentado e disfuncional e como ele chegou a provocar sérios problemas econômicos e distributivos no início desta década. Em segundo lugar, revisaremos várias tentativas de reforma do sistema de pensão. Em terceiro, revisitaremos os esforços reformistas mais recentes — os quais incluem tanto a participação dos vários sindicatos nas negociações quanto as consultas aos seus membros - explicando como este processo mais inclusivo contribuiu para o sucesso da reforma. Concluímos, analisando as lições mais gerais, que este estudo de caso pode fornecer as tentativas de reforma no futuro.

\section{2. $O$ sistema italiano de pensão: da expansão à crise}

O sistema italiano de pensão esteve entre os mais complicados e inequitativos da Europa (De CECCo e Pizzuti, 1994). Camadas de legislação particularista criaram um sistema altamente particularista, repleto de provisões especiais e regras para as diferentes categorias trabalhistas. Historicamente, servidores públicos beneficiaram-se mais desse sistema, mas com o passar do tempo, os trabalhadores do setor privado também conseguiram melhorar seus benefícios. Por exemplo, em março de 1968, as três principais confederações, a Confederazione Generale Italiana del Lavoro (CGIL), a Confederazione Italiana Sindacati Lavoratori 
(CISL) e a Unione Italiana Lavoratori (UIL) pressionaram o governo

italiano para aprovar uma reforma nas pensões que aumentasse a chamada taxa de reposição (isto é, a proporção entre os benefícios da pensão e o último pagamento) de 40 para $65 \%$ para os trabalhadores que haviam pago suas contribuições à previdência social durante 40 anos. ${ }^{2} \mathrm{Um}$ ano mais tarde, novas pressões das confederações (que organizaram duas greves gerais, em novembro de 1968 e fevereiro de 1969) induziram o governo italiano à aprovação de novas e mais generosas modificações nas pensões estatais. A taxa de reposição foi elevada de 65 para $74 \%$, e as aposentadorias foram indexadas aos preços, para salvaguardar seu poder aquisitivo (ver TuRONE, 1992: 359-62). ${ }^{3}$ Essas modificações, ao invés de abolirem os privilégios concedidos em anos anteriores aos trabalhadores do setor público, acabaram por estender alguns dos benefícios do sistema a trabalhadores da iniciativa privada.

Como resultado de tantas leis e provisões, o sistema italiano de pensão tornou-se altamente fragmentado e particularístico. Havia 47 fundos de pensão, todos caracterizados por diferentes regras para a determinação dos benefícios. A grande maioria das pensões $(85 \%)$ era paga pelo Istituto Nazionale della Previdenza Sociale (INPS); o restante, incluindo as pensões dos empregados do Estado, por um punhado de outras instituições. Mesmo no INPS, havia uma multiplicidade de fundos de pensão especiais, que amparavam várias categorias de trabalhadores. A idade mínima para aposentadoria dos trabalhadores da indústria era menor do que em todos os países ocidentais (60 anos para homens e 55 para mulheres) (ver OIT, 1989: Tabela 18, p. 84). Os benefícios de pensão eram ligados não ao valor acumulado das contribuições, e sim à remuneração recebida anteriormente. Além do mais, havia diferenças marcantes na taxa de reposição entre as várias categorias de trabalhadores. Por exemplo, no início dos anos 90, a proporção de substituição era de $73 \%$ para trabalhadores da indústria e de $100 \%$ para empregados de governos municipais e funcionários do sistema de saúde (ver Pizzuti, 1994:98). Os índices de contribuição para a previdência social também variavam enormemente entre as categorias de trabalhadores e muitos dos fundos de pensão dos agricultores, artesãos e comerciários - categorias com contribuições sociais muito baixas foram amplamente subsidiados pelo estado (via o chamado integrazione al minimo). (Para uma descrição mais detalhada das diferenças, ver Tabela 1). ${ }^{4} \mathrm{O}$ resultado destas diferenças era uma variação tremenda no valor médio das pensões entre diferentes grupos de trabalhadores (ver Tabelas 2 e 3 ).

Talvez a peculiaridade mais surpreendente do sistema italiano, e também sua maior fonte de disparidades, era a chamada "pensão por antigüidade" ( pensione di anzianita). Originalmente introduzida em 1956 
para empregados do serviço público, as "pensões por antigüidade" foram concedidas também aos trabalhadores da indústria, quase no final da década de 60. Pensões por antigüidade permitiam que os trabalhadores se aposentassem mesmo antes de atingirem a idade mínima para aposentadoria, desde que eles tivessem contribuído para suas pensões por um determinado número de anos. Aqui, novamente, esse número variava muito entre cada categoria: de 35 anos para operários da indústria a 20 anos para servidores públicos do sexo masculino e 15 anos para servidores públicos do sexo feminino que fossem casadas ou com filhos. Isto significava que uma datilógrafa, que começasse a trabalhar aos 20 anos de idade em um dos tantos ministérios em Roma, poderia começar a receber seus benefícios de pensão com 35 anos. ${ }^{5}$

As pensões por antigüidade significavam uma carga particularmente pesada para o estado, por serem pagas a pessoas relativamente jovens, com longa expectativa de vida ${ }^{6}$ dependerem menos do valor das contribuições pagas do que dos salários recebidos durante os últimos anos da carreira dos trabalhadores. Do ponto de vista da equidade, pensões por antigüidade não somente criavam diferenciações injustificadas entre grupos trabalhistas ao estabelecer condições desiguais de aposentadoria, como também (como outras pensões de idade avançada) favoreciam claramente aqueles que haviam começado a trabalhar muito jovens. Isto porque, apesar de possuírem os mesmos valores de contribuições acumuladas, estes aposentados precoces recebiam benefícios por períodos de tempo maiores. ${ }^{7}$

Somando-se a essas onerosas peculiaridades, o sistema de pensão italiana também sofria de outros problemas, comuns a outros sistemas europeus e ocidentais, baseados em esquemas de "pagamento na ativa" ("pay-as-you-go" ou PAYG). ${ }^{8}$ Tais sistemas baseiam-se em um pacto entre gerações, onde a população produtiva doa parte de seus salários para sustentar a população aposentada. A população produtiva aceita este ônus, pois espera ser sustentada, por sua vez, pelas futuras gerações produtivas. ${ }^{9}$ Um sistema de pensão baseado no mecanismo de PAYG é extremamente vulnerável a choques econômicos ou mudanças demográficas. À medida que, com o passar do tempo, haja mais ou menos a mesma proporção entre trabalhadores ativos e aposentados, o sistema PAYG distribui custos de forma igualitária entre gerações diferentes. Entretanto, tão logo a estrutura de idade comece a mudar, de forma que haja, proporcionalmente, mais aposentados que pessoas produtivas, a taxa de contribuição da previdência social, necessária à geração ativa para sustentar a manutenção do sistema de pensão em equilíbrio financeiro, torna-se insuportavelmente alta.

Outro problema com o sistema PAYG é que ele cria incentivos para decisões políticas “míopes”. Quando a proporção entre população 
ativa e aposentada é alta (como ocorreu nos anos 60 e 70 na Itália, em decorrência dos efeitos do baby boom), torna-se praticamente irresistível para legisladores aumentarem os benefícios de pensão dos aposentados, e/ou aumentarem o número de beneficiários, mantendo inalteradas (por vezes até reduzindo) as contribuições para a previdência social. ${ }^{10}$ Os efeitos dessas medidas no equilíbrio da folha do sistema de pensão podem manter-se invisíveis por muitos anos. ${ }^{11}$ Porém, uma vez introduzidas, as generosas modificações tornam-se dificilmente reversíveis, visto que passam a ser percebidas como "direitos adquiridos". Pessoas fazem planos baseados nas suas expectativas de renda, e é bastante natural que elas resistam a tentativas, mesmo que justificadas, de encurtar sua renda mensal no futuro. Esta situação de "decisão política míope" caracterizou a política das pensões na Itália durante os anos 60 e 70. De 1960 a 1975, os benefícios reais dos pensionistas cresceram em média 6,5\% ao ano. De 1975 a 1981 eles cresceram ainda mais: $8,2 \%$ por ano (OIT, 1989: Tabela 2.2:99).

Esta situação começou a mudar na década de 80: várias modificações demográficas e econômicas desafiavam a estabilidade financeira dos sistemas de pensão, tanto na Itália quanto em outros países ocidentais. Devido ao declínio das taxas de fertilidade e ao crescimento da expectativa de vida, a composição da idade da população começou a mudar drasticamente, de forma que menos pessoas jovens estavam sendo responsáveis por sustentar uma fração crescente de pessoas mais velhas e inativas. Na Itália, o envelhecimento da população tornou-se particularmente severo. No início dos anos 90, o número de filhos por mulher era 1,26 menor que em todos os outros países (ver CAzzolA, 1995;12). A essas tendências demográficas combinaram-se outras mudanças econômicas: o crescimento do desemprego reduziu o número de trabalhadores ativos, que contribuíam para o sistema de pensão, ao passo que o aumento na idade dos novos ingressantes no mercado de trabalho (devido tanto pelo aumento dos anos de formação escolar quanto pelo alto índice de desemprego entre jovens) diminuiu a média do período de contribuição. Como resultado desses acontecimentos, o equilíbrio entre trabalhadores ativos e aposentados desabou. Dentro do Fondo Pensioni Lavoratori Dipendenti (FPLD) (o maior fundo de pensão administrado pelo INPS), essa proporção caiu de 2,62, em 1963, para 1,1 em 1994 (CAzZOLA, 1995:10).

Após esta mudança, somente pela adoção de uma das três opções políticas poderia ser mantido o equilíbrio financeiro do sistema de pensão: 1) o aumento das contribuições da previdência social; 2) a redução média dos benefícios da pensão ou 3) o aumento das transferências do Tesouro para o sistema de pensão. As duas primeiras opções eram politicamente difíceis, pois implicavam em responsabilizar grupos sociais específicos pelo 
pagamento da dívida do sistema de pensão. A opção três significava que esta

dívida estava sendo de facto transferida para os ombros das futuras gerações (já que o aumento dos gastos públicos era financiado via déficit público e não através de novos impostos). Desnecessário dizer, os políticos italianos optaram pela terceira opção. Entre 1973 e 1994, o débito do INPS com o Tesouro italiano aumentou de 776 para 129.071 bilhões de liras (ver CAZzolA, 1995:16). ${ }^{12}$

Desde o final da década de 70, virtualmente todo governo italiano tinha se empenhado pela reforma do sistema de pensão. (Para uma breve descrição de cada um dos diferentes projetos de reforma, ver Tabela 4). Os vários projetos apresentavam algumas características comuns: todos tentaram aumentar a idade mínima para aposentadoria (para 65 anos para homens, e 60 anos para mulheres); todos propuseram limitar, por vezes eliminar, gradualmente, as "baby pensions" (isto é, pensões por antiguidade depois de 20 ou 15 anos de seguro somente) para empregados do serviço público; todos tentaram aumentar o intervalo de tempo com base no qual a chamada remuneração pensionável era calculada; ${ }^{13}$ e finalmente, todos tomaram providências para a introdução de esquemas de pensão suplementares, gerenciados por companhias financeiras privadas (como o projeto De Michelis, por exemplo) ou pelo estado (como era o projeto DonatCattin).${ }^{14}$ Ainda assim, nenhum dos projetos de reforma chegou a ver a luz do dia. Ao contrário, foram todos bloqueados por uma aliança peculiar (conhecida como triângulo de ferro) entre membros da Comissão Parlamentar da Reforma do Sistema de Pensão (filiados tanto ao partido majoritário quanto à oposição), vários grupos de interesse e gerentes do INPS (ver REgONINI, 1995). Na verdade, a única reforma legislativa aprovada durante os anos 80 aumentava, ao invés de reduzir, os benefícios das pensões. ${ }^{15}$

\section{Três tentativas de reforma $(1992-95)^{16}$}

\subsection{O Plano de Emergência Amato}

Os esforços para enfrentar seriamente os problemas começaram em 1992, na gestão do primeiro-ministro Amato. Confrontado com uma séria crise política e econômica, ${ }^{17}$ o governo Amato lançou (com o apoio das três principais confederações - CGIL, CISL e UIL) um plano de emergência que incluía, entre outras medidas, a abolição da scala mobile (gatilho salarial); mudanças importantes no sistema fiscal, como por exemplo, a introdução do que ficou conhecido como imposto mínimo, que visava reduzir a evasão fiscal por parte dos pequenos comerciantes e autônomos; 
e uma detalhada reforma no sistema de pensão. O objetivo principal desse plano de emergência era a redução da dívida e do déficit público, heranças da burguesia italiana, na esperança de que isso restaurasse a confiança na lira nos mercados financeiros internacionais. ${ }^{18}$

A reforma do sistema de pensão de Amato pretendia:

1) aumentar a idade mínima de aposentadoria para 65 anos para homens e 60 anos para mulheres;

2) aumentar de 5 para 10 anos o período utilizado como base de cálculo para as remunerações pensionáveis;

3) limitar a indexação das pensões (os benefícios das pensões não seriam mais indexados aos salários, somente aos preços);

4) padronizar os requisitos para pensões por antiguidade; ${ }^{19} \mathrm{e}$ finalmente

5) atrasar por um ano as autorizações para pagamento de pensões por antigüidade para trabalhadores que tivessem pago seus 35 anos de seguro. Foi estimado que a reforma iria reduzir as despesas com as pensões em 11,2 trilhões de liras em 1993, 15 trilhões de liras em 1994, e em 20 trilhões de liras em 1995. Graças a esses cortes, os gastos do maior fundo de pensão italiano, o Fondo Pensioni Lavoratori Dipendenti (FPLD) do INPS baixariam de 9.7 para $5.8 \%$ do PIB em $2025 .^{20}$

Curiosamente, apesar desses cortes substanciais, os sindicatos não se opuseram à reforma Amato. Eles tampouco convocaram greves, apesar de perceberem claramente o sentimento de inquietação que reinava em suas próprias fileiras. ${ }^{21}$

Apesar de transformar significativamente o sistema de pensão italiano, a Reforma Amato deixou sem solução vários problemas fundamentais (ver CAstellino, 1996). Primeiro, mesmo quando inteiramente implementada, a reforma manteria as diferentes idades mínimas para aposentadoria de homens (65) e mulheres (60). Essa diferença, somada à maior expectativa de vida das mulheres, era tanto inequitativa quanto cara. Em segundo lugar, mesmo tendo reformado algumas das disparidades vigentes (por exemplo, padronizando as exigências para as pensões por antigüidade), o sistema italiano ainda fragmentava-se numa pluralidade de fundos, com diferentes regras e taxas de contribuição. Terceiro, a reforma Amato deixou intocável a peculiar pensão por antigüidade italiana. Por último, e talvez o mais importante, a reforma Amato criou incentivos perversos para que os trabalhadores se aposentassem o mais cedo possível. Por exemplo, caso um trabalhador se aposentasse com 65 anos, após 43 anos de contribuição, receberia $23 \%$ a menos do que receberia se o fizesse com 57 anos de idade, tendo contribuído durante 35 anos. ${ }^{22}$ Tais incentivos, somados à possibilidade de aposentadoria após 35 anos de trabalho, contribuíram para eliminar muitas das vantagens conquistadas pelo aumento do limite para pensões de idade avançada. 
Uma segunda tentativa de reforma foi lançada pelo governo de centro-direita de Silvio Berlusconi em 1994. Berlusconi não era favorável ao apoio dos sindicatos. Além disso, ao contrário de Amato, durante sua campanha eleitoral, ele comprometeu-se a reduzir a gigantesca dívida pública da Itália (bem acima dos $100 \%$ do PIB) sem aumentar a arrecadação de impostos, somente com a redução de despesas. No entanto, as medidas orçamentárias adotadas pelos governos anteriores deixavam pouco espaço para cortes adicionais. Como resultado, ficou claro que economias no orçamento teriam de vir de um novo arrocho no sistema de pensão. Rumores de que o governo Berlusconi planejava uma profunda reconfiguração do sistema de pensão provocaram um aumento (de 84\%) no número de solicitações de pensões por antigüidade (CAZzolA, 1995:80).

O governo Berlusconi propôs as seguintes modificações no sistema de pensão:

1) uma rápida elevação da idade mínima para aposentadoria;

2) em seguida, uma desindexação das pensões (elas deveriam ser indexadas a uma inflação programada, menor que a inflação real);

3) uma redução na taxa de aumento dos benefícios das pensões de 2 para $1.75 \%$ por ano;

4) cortes nas pensões por antigüidade iguais a 3\% para cada ano que precedesse a idade mínima para aposentadoria. ${ }^{23}$

Por meio desses ajustes propostos, o governo Berlusconi pretendia enviar um sinal claro à comunidade financeira internacional de que era capaz de lidar pronta e eficientemente com os problemas macroeconômicos do país. Berlusconi esperava que esta atitude decisionista restaurasse a boa sorte da lira nos mercados internacionais. Apesar de as três confederações (CGIL, CISL e UIL) terem declarado repetidamente que não eram necessariamente contrárias à reforma, e terem demonstrado sua boa-vontade e capacidade de cooperar com os governos anteriores, o governo Berlusconi, apoiado por uma associação de empresários, a Confindustria, deliberadamente manteve-as à margem.

Em resposta, as mesmas três confederações mobilizaram-se contra a proposta de reforma. Em 14 de outubro de 1994, organizaram uma greve geral de quatro horas, junto às demonstrações massivas nas ruas em todas as grandes cidades, em protesto contra o plano do governo. Estima-se que três milhões de trabalhadores participaram da greve. Quando o governo Berlusconi recusou-se negociar com os sindicatos a respeito da reforma do sistema de pensão, elas organizaram uma nova demonstração de massa em Roma, em 12 de novembro do mesmo ano, desta vez com a participação de cerca de 1,5 milhão de pessoas. Desde o Outono Quente não se via tamanha mobilização de trabalhadores na Itália. ${ }^{24}$ 
Também como no Outono Quente, trabalhadores e seus sindicatos acolheram em suas fileiras milhares de estudantes, que protestavam contra as propostas de mudança do sistema educacional. A esse protesto nacional seguiu-se outro, dias depois, com greves limitadas em várias fábricas e cidades em todo o país.

Devido a essas mobilizações massivas, a coalisão parlamentar que apoiava o governo Berlusconi começou a desgastar-se. A Liga Norte juntou-se aos partidos de oposição, apoiando uma emenda legislativa que restaurava a taxa anual de $2 \%$ de aumento das pensões. Mesmo a Confindustria solicitou ao governo que reatasse o diálogo com os sindicatos de comércio. Os empregadores temiam que a atmosfera de confronto social intenso, provocada pela reforma do sistema de pensão, afetasse negativamente as relações industriais na empresa e/ou em determinados níveis das fábricas. As três confederações continuaram a pressionar o governo, proclamando uma nova greve geral de oito horas para o dia 2 de dezembro de 1994 . Na véspera, à noite, o governo assinou um acordo com as confederações e a greve foi cancelada. As medidas mais importantes da reforma foram retiradas da Lei Orçamentária para 1995, para serem discutidas durante negociações tripartite entre o governo, a Confindustria e as três principais confederações. Alguns dias depois de capitular as pressões, o governo Berlusconi apresentou sua renúncia.

\subsection{Finalmente a reforma: o pacto de Dini com os sindicatos}

Após a queda do gabinete de Berlusconi, as três confederações engajaram-se em um novo conjunto de negociações com o governo tecnocrata dirigido por Lamberto Dini. ${ }^{25}$ Em maio de 1995, após três meses de negociações, um acordo sobre a reforma do sistema de pensões foi assinado e enviado para aprovação do Parlamento. O Parlamento aprovou a nova lei (Lei nº 335/95) sem modificações substanciais, no dia 8 de agosto de 1995.

A nova reforma introduziu várias inovações estruturais no sistema italiano de pensão:

1) criava uma separação clara entre programas de seguro (ou seja, as pensões) e de assistência (por exemplo, benefícios de desemprego). Os primeiros deveriam ser financiados por contribuições à previdência social, deduzidas dos salários e vencimentos; os últimos seriam pagos pelo sistema geral de impostos. ${ }^{26}$

2) introduzia um novo sistema de cálculo dos benefícios de pensão, não mais baseado (como antes) na remuneração prévia, mas sim no valor das contribuições pagas por cada trabalhador. ${ }^{27}$

3) estabelecia o encerramento gradual das pensões por antigüidade e a criação de uma aposentadoria por idade flexível, dos 57 aos 65 anos. 
Cada trabalhador (homem ou mulher), desde que segurado por, pelo menos, cinco anos, poderia aposentar-se a partir dos 57 anos de idade. $\mathrm{O}$ valor das pensões, no entanto, dependeria diretamente do valor das contribuições acumuladas. Deste modo, aqueles que tivessem períodos de contribuição mais longos receberiam pensões maiores. Além disso, a reforma estabelecia multas para aqueles que se aposentassem antes dos 65 anos. Essas multas equivaliam a aproximadamente $3 \%$ para cada ano antes dos 65 anos. Assim, a multa de 3\%, tão amargamente contestada pelos sindicatos, quando proposta por Berlusconi, era reintroduzida na Reforma Dini com apoio dos sindicatos (ver CASTELLINO, 1996: 187). ${ }^{28}$

4) o novo sistema unificava os vários esquemas de pensão para as diferentes categorias trabalhistas. As contribuições foram uniformemente estabelecidas em $32 \%$ para todas as categorias de trabalhadores do setores público e privado, e em 15 ou $16 \%$ para os autônomos. ${ }^{29}$

5) finalmente, estabeleceu-se uma estrutura para a criação de fundos suplementares de pensão, administrados pela iniciativa privada, com base em esquemas de financiamento integral. Muitos dos detalhes relativos à constituição destes novos fundos de pensão foram encaminhados para negociação coletiva entre as partes envolvidas (sindicatos, empregadores e cooperativas). $\mathrm{O}$ governo estipulou, no entanto, algumas diretrizes importantes, referentes à possibilidade do financiamento desses fundos suplementares com parte das reservas acumuladas para o pagamento de indenizações (conhecido como Trattamento di Fine Rapporto - TFR) e o abatimento parcial desses fundos do imposto de renda. ${ }^{30}$

A nova reforma estrutural do sistema de pensão criou incentivos claros, para que os trabalhadores adiassem suas aposentadorias, aumentando dessa forma a entrada de capital por períodos de contribuição mais longos, ao mesmo tempo que reduzia a saída de capital limitando os pagamentos da pensão para poucos anos.

Apesar de tudo, a implementação da Reforma Dini não aconteceu sem dificuldades. No início do processo, a Confindustria retirou-se das negociações, negando-se mais tarde a assinar o acordo. A Confindustria opunha-se à reforma, argumentando que ela não incluía reduções (de fato, provocava até um ligeiro aumento) nas contribuições para a previdência social (pagas, na sua maioria, pelos empregadores, e constituindo uma porção razoável dos custos laborais), e porque muitas das maiores e mais diversificadas companhias representadas pela Confindustria esperavam ampliar seu controle dentro do promissor mercado de fundos de pensão privados. Essas companhias argumentavam que uma reforma que garantia o pagamento de pensões equivalentes a, em média, $65 \%$ dos vencimentos, não deixava muito espaço para a constituição de fundos suplementares privados. Curiosamente, a redução de gastos prevista pela Reforma Dini era mais ou menos comparável àquela projetada pelo (fracassado) projeto 
de Berlusconi (ver Tabela 5). As principais diferenças estavam na fonte dos cortes. Enquanto a proposta de Berlusconi concentrava sua economia na redução de pensões por antigüidade, a Reforma Dini distribuía os custos do arrocho entre uma base social maior (ver Tabela 6). ${ }^{31}$

Mas talvez a maior surpresa de todas seja o fato de uma reforma estrutural tão drástica ter realmente acontecido, especialmente considerando-se a extrema heterogeneidade dos interesses afetados. ${ }^{32}$ Empregados do setor público foram privados de todos os seus privilégios especiais. No setor de serviços, havia vários grupos de trabalhadores que não poderiam mais contar com normas particularísticas utilizadas na determinação dos seus benefícios. Empregados do setor elétrico, por exemplo, tinham uma taxa de aumento de pensões de $3 \%$ ao ano, ao invés dos $2 \%$ dos outros trabalhadores. Motoristas de ônibus tinham suas pensões calculadas com base numa remuneração pensionável que incluía somente os últimos seis meses de trabalho, e não os últimos cinco anos, e beneficiavam-se de uma taxa de aumento de 2,5\%. ${ }^{33}$ Para todos esses grupos, as regras foram unificadas. Mesmo nos setores industriais, os interesses eram diversificados. Trabalhadores do ramo têxtil, predominantemente do sexo feminino, tinham sido historicamente contrários a todas as tentativas de aumento da idade pensionável para mulheres (ver Regonini, 1990:353). Metalúrgicos, na sua maioria homens de meia-idade, eram veementemente contra qualquer quebra da regra dos 35 anos para as pensões por antigüidade. Outros trabalhadores, como os do ramo da construção civil, estavam dispostos a abrir mão das pensões por antigüidade (a natureza descontinuada de seus empregos dificultava o acúmulo de 35 anos de contribuição), mas pretendiam manter inalterado o valor das pensões por idade. Como conciliar tantos interesses conflitantes? E por que os sindicatos italianos teriam concordado com mudanças tão profundas no sistema de pensão?

\section{A agregação de interesses pela via da decisão democrática}

À primeira vista, a reforma do sistema de pensão italiano de 1995 parece aproximar-se do clássico esquema neocorporativista, onde as políticas sociais eram negociadas entre o governo e os aliados sociais. Segundo vários autores, esta modalidade de decisão conjunta aumenta tanto a factibilidade quanto a legitimidade das políticas públicas (ver SCHMITTER, 1981; LEHMBRUCH, 1979). No entanto, a reforma italiana difere em grande parte do modelo neocorporativista, quando se considera o processo através do qual a agregação/intermediação de interesses foi alcançada. Ao contrário das previsões da teoria neocorporativista, os sindicatos italianos pretendiam resolver os múltiplos conflitos surgidos a partir de suas formações, não 
adotando estruturas hierárquicas de tomada de decisão, mas sim promovendo a discussão democrática entre diferentes grupos de trabalhadores.

Segundo grande parte da literatura sobre o processo decisório neocorporativista, quando os sindicatos buscam representar bases diversas (ou seja, trabalhadores com aptidões distintas, empregados em setores diferentes), acabam engajando-se em uma negociação difícil entre o interesse particular e o geral (REGINI, 1981). Por outro lado, sua preocupação com o desempenho econômico nacional encoraja-os a elaborar agendas de negociação que tomam em consideração várias dificuldades macroeconômicas. Além do mais, eles subexploram o poder do mercado pelo menos de alguns grupos trabalhistas. Como resultado dessas pressões conflitantes, o auge das discussões geralmente promove uma dissidência interna e uma fragmentação na organização dos sindicatos. ${ }^{34}$

A necessidade de isolar as lideranças trabalhistas dessas forças centrífugas explica a importância que virtualmente todos os autores atribuem a certas características organizacionais, tais como hierarquia interna, centralização e monopólio da representação. ${ }^{35}$ Medidas como reconhecimento legal, filiação compulsória, cobrança automática de dívidas do sindicato são planejadas para evitar a saída dos trabalhadores de suas fileiras (OFFe, 1981). O acesso direto a fundos públicos fornece às lideranças trabalhistas recursos provenientes diretamente do Estado, tornando-as independentes do apoio voluntário de seus membros (LANGE, 1984). Finalmente, a hierarquia organizacional e a centralização da tomada de decisão nas mãos de um limitado número de líderes sindicais restringem a possibilidade de membros externarem suas preocupações. ${ }^{36}$

No entanto, a proteção da competição exterior e a obstrução de qualquer dissidência interna não se mostrou suficiente no sentido de evitar a deslegitimação das hierarquias dos sindicatos e/ou de prevenir sua fragmentação. Na Suécia, por exemplo, o considerável poder organizacional exercido pela poderosa confederação operária Landsorganizationen $i$ Sverige (LO) sobre seus afiliados na indústria não evitou (talvez tenha até impulsionado) o surgimento de clivagens múltiplas entre os vários grupos de trabalhadores: especializados versus não especializados, homens versus mulheres, artesãos versus escriturários, empregados do setor privado versus empregados do setor público. Tais acontecimentos levaram ao colapso da negociação centralizada (MARTin, 1992; Pontusson e SwENSON, 1993).

Na Itália, os esforços para que fossem introduzidas as pré-condições institucionais para a tomada de decisão neocorporativista, através da centralização de estruturas dos sindicatos, na verdade, aumentaram a fragmentação e a descentralização das relações industriais. ${ }^{37}$ Inúmeras categorias trabalhistas (principalmente trabalhadores mais especializados do setor público) sentiram que suas demandas eram pouco valorizadas pelos sindicatos hierarquicamente organizados. Na segunda metade dos anos 80, 
esses trabalhadores começaram a desertar e criaram suas próprias organizações autônomas (chamados sindacati autonomi ou comitati di basi COBAS). Com seu agressivo comportamento nas negociações e o freqüente recurso da greve, essas novas organizações aumentaram a anarquia e o conflito nas relações industriais italianas (LOCKE e BACCARO, 1996a).

O fracasso das práticas tradicionais neocorporativistas, tanto na Itália como no exterior, influenciou visivelmente a liderança trabalhista italiana, à medida que estas passaram a participar das negociações sobre a reforma do sistema de pensão. As confederações estavam conscientes de que arriscavam comprometer sua coesão interna, visto que a reforma impunha perdas significativas para muitos grupos de trabalhadores. Desta forma, elas resistiram à tentação de negociar com o governo "a portas fechadas" e, por sua vez, engajaram-se na que pode ser considerada a maior experiência no terreno da democracia dos sindicatos italianos. ${ }^{38}$

Em outras palavras, depois de elaborar sua posição na reforma do sistema de pensão, as três confederações consultaram suas bases por meio de assembléias organizadas nas principais fábricas e escritórios em toda a Itália. Essa consulta, em larga escala, aos membros mostrou que havia grandes grupos de trabalhadores que se opunham aos cortes indiscriminados nas pensões. Em particular, muitos trabalhadores que participavam das assembléias recusavam-se a aceitar que a nova reforma reduzisse a possibilidade dos trabalhadores de meia-idade de se aposentarem após 35 anos de serviço, ou diminuísse a taxa de aumento das pensões. Em essência, os trabalhadores não queriam reduções generalizadas na taxa de reposição, ou seja, a proporção entre a primeira parcela da pensão e o último pagamento. ${ }^{39}$

As confederações discutiram essas demandas com o governo e juntos tentaram fazer a distinção entre as solicitações legítimas e as inaceitáveis. Por exemplo, o pedido de aposentadoria precoce seria considerado justificável se partisse de trabalhadores envolvidos em trabalhos extenuantes ou de alta periculosidade ${ }^{40}$ mas inaceitável por parte daqueles empregados desempenhando funções burocráticas em escritórios. ${ }^{41}$ Assim, a reforma de 1995 continha cláusulas especiais para os empregados em lavori usuranti (ou seja, funções monótonas, extenuantes e/ou de alta periculosidade). Tais trabalhadores podiam antecipar suas aposentadorias em até dois anos. Também para evitar reduções generalizadas no valor dos benefícios, a Reforma Dini concentrou as reduções de benefícios sobre aqueles trabalhadores que optassem pela aposentadoria antecipada. Por exemplo, um trabalhador de uma indústria que se aposentasse aos 65 anos (idade máxima para aposentadoria), após 43 anos de contribuição receberia uma pensão $27 \%$ maior que no regime anterior. Entretanto, se o mesmo operário decidisse aposentar-se aos 57 anos de idade 
(idade mínima para aposentadoria) e com apenas 35 anos de contribuição, receberia $12 \%$ a menos do que receberia de acordo com o sistema prévio (ver BANCA D’ITÁLIA, 1994: Tabela 1, p. 17).

Após a primeira tentativa de assinatura do acordo, no dia 8 de maio de 1994, as confederações organizaram uma nova onda de assembléias (cerca de 42 mil) nas principais fábricas e escritórios, e um referendo final sobre o acordo, realizado entre 30 de maio e $1^{\circ}$ de junho de $1995 .{ }^{42}$ As assembléias eram geralmente estruturadas dessa forma: as lideranças de um sindicato detalhavam o conteúdo do acordo, discutindo a inevitabilidade da reforma, em decorrência das ineficiências e ineqüidades inerentes ao antigo sistema, e explicando por que projetos alternativos de reforma eram indesejáveis. A essa apresentação seguia-se um debate, onde os trabalhadores perguntavam sobre a sua situação específica, expressavam suas opiniões sobre assuntos morais/distributivos mais importantes, como a necessidade de pensão assegurada para as futuras gerações, ${ }^{43}$ ou apresentavam sugestões de como eliminar as ineqüidades existentes (por exemplo, acelerando a transição para um novo regime para servidores públicos).

Muitas vozes dissidentes foram ouvidas durante esses debates. Embora a Reforma Dini oferecesse uma transição gradual para o novo regime, ela negava a trabalhadores com menos de 28 anos de seguro pago seu direito de receber pensões por antigüidade após 35 anos de trabalho. Esta era, em muitos casos, uma parcela crítica de trabalhadores. Muitos deles haviam entrado no mercado de trabalho no final dos anos 60, e participado da onda de greves do Outono Quente, entre o final da década de 60 e o início dos anos 70 (Pizzorno et al., 1978; S ABEL, 1982). Esses trabalhadores estavam agora aproximando-se do momento da aposentadoria, e viam de forma muito crítica as novas regras que reduziam as pensões por antigüidade. ${ }^{44}$ Suas exigências foram prontamente endossadas por alguns grupos de sindicatos mais esquerdistas, como o Essere Sindacato (uma facção interna do CGIL) e o Comitati di Basi (COBAS) ${ }^{45}$ Curiosamente, no entanto, mesmo aqueles trabalhadores que recusaram o acordo, declararam publicamente, em várias ocasiões, que preferiam externar seu desacordo no interior dos seus sindicatos estabelecidos (e desta forma tentar convencer os colegas) do que debandar para outra organização e, desta forma, comprometer a unidade do movimento trabalhista italiano. ${ }^{46}$

As 42 mil assembléias foram seguidas de um referendo. Entre 30 de maio e $1^{\text {o }}$ de junho de 1995 houve eleições em 49 mil diferentes locais, em todo o país, incluindo fábricas, escritórios, sedes de sindicatos e administrações municipais. ${ }^{47}$ Trabalhadores ativos (sindicalizados ou não), desempregados e aposentados puderam votar. Votaram 4,5 milhões de pessoas, e 64\% delas aprovaram a reforma (ver Tabela 7). 
Os pensionistas, em peso, votaram a favor do acordo (91\%). Esta não foi uma surpresa à medida que a reforma limitava somente os benefícios dos futuros aposentados. Trabalhadores ativos também aprovaram a reforma, porém com um percentual menor - 58\% (ver Tabela 8). A maior parte das federações industriais endossou a reforma, apesar de seu nível de apoio variar em setores e regiões. No entanto, na Lombardia, a região mais rica e industrializada da Itália, os trabalhadores ativos rejeitaram a proposta. Além disso, duas categorias trabalhistas importantes, metalúrgicos e professores, também negaram o acordo. Ambas federações tinham uma longa tradição de militância. Os metalúrgicos representavam uma vanguarda histórica do movimento trabalhista italiano. Foram eles que, entre o final dos anos 60 e o início da década de 70, iniciaram o movimento Outono Quente de greves. No início dos anos 80 , sua oposição às políticas salariais solapou a tentativa italiana de estabelecer uma modalidade de decisão política tripartite (GOLDEN, 1988). Os professores também eram extremamente militantes. Em 1986, eles iniciaram uma onda de greves ilegais que estendeu-se rapidamente a outros setores públicos, como os ferroviários e empregados de transportes aéreos (BALDisserA, 1988; BordognA, 1988; LoMBARDI, 1989). Vários professores desertaram de seus sindicatos e criaram suas próprias organizações, as chamadas Comitati di Base (COBAS).

Tempos atrás, a oposição de metalúrgicos (sem contar os professores) e da maioria dos trabalhadores da Lombardia teria significado o fracasso da reforma, mas, em função do processo democrático pelo qual ela foi discutida e votada, os metalúrgicos e professores acabaram aceitando-na. Em suma, a participação dos sindicatos no processo de reforma não levou nem à sua apropriação nem ao seu fracasso, mas garantiu o apoio político necessário para seu sucesso.

\section{Considerações finais}

Este documento descreveu os recentes esforços por uma reforma no sistema de pensão italiano. O processo ilustrou dois pontos distintos, mas interligados. $\mathrm{O}$ primeiro refere-se ao papel potencial dos sindicatos na reforma do setor público. O segundo, enfoca a importância da deliberação democrática no desenho das preferências políticas.

Contrariando muito do que já se escreveu sobre a reforma do setor público/estado de bem-estar, que invariavelmente receita o isolamento dos decisores governamentais das pressões de grupos de interesse, a experiência italiana demonstra que os sindicatos podem desempenhar um papel positivo na promoção da reforma. Para tanto, porém, eles devem participar do processo de reforma. Na Itália, sindicatos resistiram durante 
anos às mudanças no sistema de pensão. Os benefícios vigentes haviam

ganhado o status de benefícios adquiridos e eram, assim, defendidos por todos os meios. Conseqüentemente, todos os repetidos esforços em direção a uma reforma no sistema italiano de pensão, durante toda a década de 80 , foram derrubados. No entanto, assim que foram convidados pelo governo Dini a participar do processo da reforma, os sindicatos conseguiram superar a oposição às medidas e apoiar a reforma.

A participação envolveu não só as lideranças trabalhistas que negociaram as várias mudanças com altos funcionários do governo, mas também os membros dos sindicatos, que participaram de milhares de assembléias e votaram a reforma proposta. Esse processo democrático de deliberação e tomada de decisão proporcionou aos trabalhadores italianos a oportunidade não somente de aprender mais sobre a proposta, mas de expressar suas opiniões sobre aspectos particulares da reforma. Em alguns casos, como na aposentadoria por idade para trabalhadores com empregos fisicamente desgastantes, suas opiniões acarretaram modificações na própria proposta de reforma. Acima de tudo, as assembléias encorajaram um processo pelo qual as preferências não eram somente expressas, mas também elaboradas de formas que filtrassem preocupações muito setorizadas. Em outras palavras, no decorrer desse debates, alguns trabalhadores perceberam que, apesar de a proposta desafiar seus interesses imediatos, ela inegavelmente atendia a interesses sociais maiores, como a preservação do sistema de pensão para as gerações futuras. Grupos poderosos, como os metalúrgicos e professores, não mudaram suas preferências; no entanto, ao perceberem um processo aberto e democrático, eles concordaram com a decisão da maioria de apoiar a reforma.

Tal fato sugere que a tomada de decisão democrática tem uma influência institucional poderosa sobre a formação e/ou manifestação de preferências políticas. A necessidade de justificar solicitações individuais por meio de referência tanto a princípios quanto a interesses generalizados, leva os participantes de uma assembléia deliberativa a suprimirem aqueles argumentos políticos que, baseados somente em interesse próprio, não podem ser facilmente defendidos e aceitos por outros. Isto, por sua vez, fornece aos argumentos que consideram os interesses de outras pessoas uma oportunidade privilegiada de emergir no debate (BACCARO, 1996). É claro que a argumentação sobre democracia deliberativa não pode ser convincentemente demonstrada pela análise deste caso. Ela necessita de uma pesquisa muito mais sistemática e comparativa. 
Tabela 1: Regras de elegibilidade, esquemas de contribuição e determinação de benefícios de pensão (1990)

\begin{tabular}{|c|c|c|c|}
\hline & INPS (a) & Estado (b) & Governos municipais (c) \\
\hline \multirow[t]{2}{*}{$\begin{array}{l}\text { Contribuição para } \\
\text { a previdência social }\end{array}$} & $\begin{array}{l}\text { 19,26\% (emprega- } \\
\text { dores) }\end{array}$ & não especificado & 17,7\% (empregadores) \\
\hline & $\begin{array}{l}7,15 \% \text { (trabalha- } \\
\text { dores) }\end{array}$ & $\begin{array}{l}6,75 \% \text { (trabalha- } \\
\text { dores) }\end{array}$ & $6,55 \%$ (trabalhadores) \\
\hline Pensão por idade & $\begin{array}{l}60 \text { anos (homens) e } \\
55 \text { anos (mulheres) } \\
\text { com } 15 \text { anos de con- } \\
\text { tribuição }\end{array}$ & $\begin{array}{l}65 \text { anos (homens) } \\
\text { e } 60 \text { anos (mulhe- } \\
\text { res) com } 15 \text { anos } \\
\text { de contribuição }\end{array}$ & $\begin{array}{l}60 \text { anos (homens e } \\
\text { mulheres) com } 25 \\
\text { de contribuição }\end{array}$ \\
\hline $\begin{array}{l}\text { Pensões por } \\
\text { antigüidade }\end{array}$ & $\begin{array}{l}35 \text { anos de contri- } \\
\text { buição }\end{array}$ & $\begin{array}{l}20 \text { anos de contri- } \\
\text { buição ( } 15 \text { anos } \\
\text { para mulheres } \\
\text { casadas) }\end{array}$ & $\begin{array}{l}25 \text { anos de contribuição } \\
\text { ( } 20 \text { anos para mulheres } \\
\text { casadas) }\end{array}$ \\
\hline $\begin{array}{l}\text { Remuneração de } \\
\text { pensões }\end{array}$ & $\begin{array}{l}\text { remuneração média } \\
\text { dos últimos } 5 \text { anos }\end{array}$ & $\begin{array}{l}\text { últimos salários } \\
\text { mensais (acresci- } \\
\text { dos de } 18 \% \text { ) }\end{array}$ & $\begin{array}{l}\text { últimos salários } \\
\text { mensais }\end{array}$ \\
\hline Valor da pensão & $\begin{array}{l}80 \% \text { da base } \\
\text { pensionável (após } \\
40 \text { anos) (d) }\end{array}$ & $\begin{array}{l}95 \% \text { do último } \\
\text { salário (após } \\
40 \text { anos) }\end{array}$ & $\begin{array}{l}100 \% \text { do último } \\
\text { salário (após } 40 \\
\text { anos) }\end{array}$ \\
\hline Indexação & Preços e salários & Preços e salários & Preços e salários \\
\hline
\end{tabular}

(a) O Istituto Nazionale per la Previdenza Sociale (INPS) administra fundos de pensão diferentes, que amparam trabalhadores da indústria privada, agricultores, artesãos, lojistas e outras categorias especiais (tais como funcionários de empresas de transporte, telecomunicações, eletricidade, clero, etc).

(b) Funcionários estaduais, incluindo professores.

(c) Empregados de governos municipais e de serviços de saúde.

(d) Corresponde a aproximadamente $83 \%$ do último salário.

Fonte: Adaptado de Censis, Rapporto sulla situazione sociale del paese, 1991. Milão: Franco Angeli, 1991: 434.

Tabela 2: Pensões de invalidez, idade avançada e viuvez para diferentes categorias trabalhistas (1992)

\begin{tabular}{|c|c|c|c|c|}
\hline & $\begin{array}{c}\text { Número } \\
\text { (milhares) }\end{array}$ & $\begin{array}{l}\text { Média (milha- } \\
\text { res de liras) }\end{array}$ & Valor $(\%)$ & $\begin{array}{l}\% \text { do Produto } \\
\text { Interno Bruto }\end{array}$ \\
\hline $\begin{array}{l}\text { 1. Trabalhadores da } \\
\text { indústria (FPLD) }\end{array}$ & 10.005 & 10.868 & 96 & 7,2 \\
\hline 2. Autônomos & 3.536 & 6.783 & 60 & 1,6 \\
\hline 2.1 agricultores & 1.994 & 6.718 & 59 & 0,9 \\
\hline 2.2 artesãos & 787 & 7.177 & 63 & 0,4 \\
\hline 2.3 lojistas & 755 & 6.551 & 58 & 0,3 \\
\hline $\begin{array}{l}\text { 3. Servidores públicos } \\
3.1 \text { funcionários }\end{array}$ & 1.933 & 22.258 & 196 & 2,8 \\
\hline estaduais & 1.276 & 23.258 & 203 & 1,9 \\
\hline $\begin{array}{c}3.2 \text { funcionários } \\
\text { municipais }\end{array}$ & 657 & 20.685 & 192 & 0,9 \\
\hline 4. Total & 15.474 & 11.357 & 100 & 11,6 \\
\hline
\end{tabular}

Fonte: Felice Roberto Pizzuti, "Note sul sistema pensionistico italiano." Em Marcello De Cecco e Felice Roberto Pizzuti, eds. La politica previdenziale in Europa. Bolonha: Il Mulino, 1994:Tab.1, p. 51 
Tabela 3: Número e valor das pensões de idade avançada administradas pelo INPS no final de 1994

\begin{tabular}{lccc}
\hline Trabalhadores & $\begin{array}{l}\text { Número de } \\
\text { pensões }\end{array}$ & $\begin{array}{l}\text { Valor médio por ano } \\
\text { (em milhares de liras) }\end{array}$ & \\
\hline Trabalhadores da indústria (FPLD) & 5.130 .007 & 14.796 & 106 \\
\hline Trabalhadores agrícolas & 719.682 & 9.114 & 65 \\
\hline Artesãos & 380.703 & 10.734 & 77 \\
\hline Lojistas & 414.709 & 8.776 & 63 \\
\hline $\begin{array}{l}\text { Trabalhadores de meios de } \\
\text { transportes }\end{array}$ & 63.043 & 31.565 & 225 \\
\hline $\begin{array}{l}\text { Trabalhadores de meios de } \\
\text { comunicação }\end{array}$ & 26.218 & 35.289 & 252 \\
\hline $\begin{array}{l}\text { Trabalhadores de fiscalização } \\
\text { tributária }\end{array}$ & 6.213 & 26.044 & 186 \\
\hline Trabalhadores eletricistas & 44.803 & 34.250 & 244 \\
\hline Funcionários de empresas aéreas & 1.840 & 43.727 & 312 \\
\hline Mineiros & 6.327 & 21.143 & 151 \\
\hline $\begin{array}{l}\text { Trabalhadores de utilidade pública } \\
\text { (como empresas de gás) }\end{array}$ & 3.210 & 30.087 & 215 \\
\hline Coletores de impostos & 5.574 & 35.816 & 256 \\
\hline \begin{tabular}{l} 
Clero \\
\hline Total
\end{tabular} & 13.129 & 9.452 & 67 \\
\hline & 6.815 .458 & 14.003 & 100 \\
\hline
\end{tabular}

Fonte: Adaptado de Giuliano Cazzola, Le nuove pensioni degli Italiani. Bolonha: Il Mulino, 1994: Tabela 3, p. 48-9 
Tabela 4:

Resumo das reformas de pensões fracassadas (1984-91)

\begin{tabular}{|c|c|c|c|c|}
\hline & De Michelis (1989) & Formica (1989) & Donat Cattin (1990) & Marini (1991) \\
\hline Idade mínima para aposentadoria & 65 (homens e mulheres) & 65 (homens e mulheres) & 65 (homens e mulheres) & 65 (homens e mulheres) \\
\hline Períodos de contribuição (mínimo) & 20 anos & $\begin{array}{l}20 \text { (homens) e } 15 \text { anos } \\
\text { (mulheres) }\end{array}$ & 15 anos & 15 anos \\
\hline Remuneração pensionável & $\begin{array}{l}\text { Remuneração média dos } \\
\text { últimos } 10 \text { anos }\end{array}$ & $\begin{array}{l}\text { Remuneração média dos } \\
\text { últimos } 10 \text { anos }\end{array}$ & $\begin{array}{l}\text { Remuneração média dos } \\
\text { últimos } 10 \text { anos }\end{array}$ & $\begin{array}{l}\text { Remuneração média dos } \\
\text { últimos } 10 \text { anos }\end{array}$ \\
\hline Pensão por antigüidade & Após 35 anos & Após 35 anos & Após 40 anos & Após 35 anos \\
\hline Valor da pensão & $\begin{array}{l}80 \% \text { do salário-base } \\
\text { (após } 35 \text { anos) }\end{array}$ & $\begin{array}{l}80 \% \text { do salário-base } \\
\text { (após } 35 \text { anos) }\end{array}$ & $\begin{array}{l}\text { 80\% do salário-base } \\
\text { (após } 40 \text { anos) }\end{array}$ & $\begin{array}{l}80 \% \text { do salário-base } \\
\text { (após } 40 \text { anos) }\end{array}$ \\
\hline Indexação & salários & salários & salários & salários \\
\hline $\begin{array}{l}\text { Harmonização entre regimes de } \\
\text { pensão para funcionários públi- } \\
\text { cos e da iniciativa privada }\end{array}$ & $\operatorname{sim}$ & $\operatorname{sim}$ & $\operatorname{sim}$ & $\operatorname{sim}$ \\
\hline Esquemas de pensão suplementar & $\operatorname{sim}$ & $\operatorname{sim}$ & $\operatorname{sim}$ & $\operatorname{sim}$ \\
\hline
\end{tabular}

Fonte: Adaptado de CENSIS, Rapporto sulla situazione generale del paese, 1991. Milão: Franco Angeli, 1991: 421 
Tabela 5: As reformas do sistema de pensão de Berlusconi e Dini.

Previsão de redução orçamentária (em bilhões de liras)

\begin{tabular}{lccccccccccc}
\hline & 1996 & 1997 & 1998 & 1999 & 2000 & 2001 & 2002 & 2003 & 2004 & 2005 & Total \\
\hline 1. Berlusconi (a) & 6.911 & 7.570 & 5.398 & 8.437 & 11.690 & 14.106 & 15.003 & 15.993 & 16.936 & 17.793 & 119.837 \\
\hline 2. Dini (b) & 8.629 & 6.816 & 8.224 & 9.223 & 10.319 & 11.472 & 12.210 & 12.932 & 13.451 & 15.020 & 108.296 \\
\hline
\end{tabular}

(a) cortes segundo cálculo do Gabinete de Orçamento. Os dados inicialmente fornecidos pelo Governo superestimavam a redução nos gastos.

(b) dados (fornecidos pelo governo) correspondem às estimativas preparadas por Il Sole - 24 Ore (o maior jornal financeiro da Itália)

Fonte: Giuliano Cazzola, Le nuove pensioni degli Italiani. Bolonha, Il Mulino, 1995: Tabelas 7 e 8, p. 110-1 e 114.

Tabela 6: Análise da redução dos gastos orçamentários da

Reforma Dini no sistema de pensões (em bilhões de liras)

$\begin{array}{ll}\begin{array}{l}\text { Redução } \\ (1996-2005)\end{array} & \text { \% do total da redução } \\ & (1996-2005) \text { (a) }\end{array}$

\begin{tabular}{l}
$\begin{array}{l}\text { 1. Cortes nas pensões por } \\
\text { antigüidade }\end{array}$ \\
\hline
\end{tabular}

2. Contribuições sociais para o $\quad 30.827$

"lavoro parasubordinato" (b)

3. Novas contribuições para a

previdência social (c) $\quad 26.843 \quad 18$

4. Mudanças nas pensões de viuvez (d) $\quad 16.424 \quad 11$

a) A redução prevista no orçamento, em decorrência da Reforma Dini, é de 147.784 bilhões de liras. Essa economia, no entanto, é em parte compensada pela entrada reduzida de impostos (-34.835 bilhões de liras), em função principalmente do regime favorável de impostos, transferidos para os fundos de pensão privados. (-13.639 bilhões de liras).

b) A categoria de "lavoro parasubordinato" inclui aqueles trabalhadores (especialmente jovens profissionais) que, enquanto contratados formalmente como consultores por meio período, exercem de facto as mesmas tarefas que outros empregados contratados para período integral. Anteriormente, essa categoria não era coberta por nenhuma pensão estadual, financiada por contribuições de previdência social. Conseqüentemente, os custos laborais para empregados dessa categoria trabalhista eram menores que os custos com empregados com contratos para período integral. A Reforma Dini estendeu compulsoriamente as contribuições para a previdência social (iguais a $10 \%$ do pagamento, dos quais $2 / 3$ são pagos pelo empregador e $1 / 3$ é pago pelo trabalhador) para o "lavoro parasubordinato" também.

c) A Reforma Dini elevou o total das contribuições para a previdência social em $0,7 \%$ : $0,35 \%$ pagos pelos empregadores, $0,35 \%$ pelos empregados.

d) Redução dos pagamentos para viúvos ou viúvas de membros segurados.

Fonte: Giuliano Cazzola, Le nuove pensioni degli Italiani. Bolonha: Il Mulino, 1995: Tabela 7 , p. 110-1 (cálculos dos autores). 
Tabela 7: Resultados do referendo sobre

o sistema de pensão (todos os eleitores)

\begin{tabular}{lrrll}
\hline Regiões & Eleitores & $\begin{array}{l}\text { Votos } \\
\text { válidos }\end{array}$ & $\begin{array}{l}\text { Votos } \\
\text { a favor }(\%)\end{array}$ & $\begin{array}{l}\text { Votos } \\
\text { contra (\%) }\end{array}$ \\
\hline Piemonte & 408.365 & 400.900 & 52,64 & 47,36 \\
\hline Valle D'Aosta & 6.800 & 6.682 & 59,55 & 40,45 \\
\hline Liguria & 150.235 & 147.875 & 58,84 & 41,16 \\
\hline Lombardia & 881.604 & 867.128 & 52,45 & 47,55 \\
\hline Veneto & 334.367 & 328.210 & 62,47 & 37,53 \\
\hline Trentino - Alto Adige & 44.939 & 43.638 & 58,46 & 41,54 \\
\hline Friuli Veneza Giulia & 83.702 & 82.106 & 64,08 & 35,92 \\
\hline Emilia Romagna & 603.442 & 594.487 & 71,47 & 28,53 \\
\hline Toscana & 323.665 & 319.124 & 64,86 & 35,14 \\
\hline Marche & 112.148 & 110.201 & 69,38 & 30,62 \\
\hline Umbria & 68.164 & 67.103 & 66,89 & 33,11 \\
\hline Lazio & 353.799 & 349.789 & 64,40 & 35,60 \\
\hline Abruzzo & 65.202 & 63.998 & 62,57 & 37,43 \\
\hline Molise & 16.392 & 16.102 & 74,28 & 25,72 \\
\hline Campania & 236.997 & 223.632 & 69,54 & 30,46 \\
\hline Puglia & 192.907 & 190.332 & 73,56 & 26,44 \\
\hline Basilicata & 30.576 & 30.115 & 73,16 & 26,84 \\
\hline Calábria & 121.689 & 119.168 & 82,56 & 17,44 \\
\hline Saŕlia & 304.556 & 298.903 & 79,53 & 20,47 \\
\hline Total & 89.547 & 87.842 & 68,94 & 31,06 \\
\hline
\end{tabular}

Fonte: Nuova Rassegna Sindacale, n. 26, 10 de julho de 1995. 
Tabela 8: Resultados do referendo sobre o sistema de pensão (trabalhadores ativos)

\begin{tabular}{|c|c|c|c|c|}
\hline Regiões & Eleitores & $\begin{array}{l}\text { Votos } \\
\text { válidos }\end{array}$ & $\begin{array}{l}\text { Votos } \\
\text { a favor }\end{array}$ & $\begin{array}{l}(\%) \text { Votos } \\
\text { contra }(\%)\end{array}$ \\
\hline Piemonte & 400.933 & 393.371 & 50,68 & 49,32 \\
\hline Valle D'Aosta & 6.339 & 6.226 & 58,26 & 41,74 \\
\hline Liguria & 125.048 & 122.786 & 51,99 & 48,01 \\
\hline Lombardia & 782.930 & 768.694 & 47,38 & 52,62 \\
\hline Veneto & 276.709 & 270.715 & 56,77 & 43,23 \\
\hline Trentino - Alto Adige & 41.452 & 40.170 & 56,34 & 43,66 \\
\hline Friuli Veneza Giulia & 70.601 & 69.045 & 58,67 & 41,33 \\
\hline Emilia Romagna & 429.138 & 420.951 & 61,96 & 38,04 \\
\hline Toscana & 258.914 & 254.660 & 58,29 & 41,71 \\
\hline Marche & 84.642 & 82.790 & 61,56 & 38,44 \\
\hline Umbria & 50.916 & 49.896 & 60,18 & 39,82 \\
\hline Lazio & 311.853 & 308.035 & 60,45 & 39,55 \\
\hline Abruzzo & 59.046 & 57.308 & 59,62 & 40,38 \\
\hline Molise & 12.594 & 12.381 & 68,89 & 31,11 \\
\hline Campania & 183.196 & 180.379 & 61,42 & 38,58 \\
\hline Puglia & 155.996 & 153.418 & 69,20 & 30,80 \\
\hline Basilicata & 24.306 & 23.845 & 71,70 & 28,30 \\
\hline Calabria & 89.631 & 87.615 & 78,70 & 21,30 \\
\hline Sicília & 194.019 & 190.588 & 75,57 & 24,43 \\
\hline Sardenha & 67.004 & 65.299 & 62,17 & 37,83 \\
\hline Total & 3.625 .267 & 3.558 .172 & 57,75 & 42,25 \\
\hline
\end{tabular}

Fonte: Nuova Rassegna Sindacale, n. 26, 10 de julho de 1995. 
Tabela 9: Resultados do referendo sobre o sistema de pensão (por categoria de trabalhadores)

\begin{tabular}{|c|c|c|c|c|}
\hline Categorias & Eleitores & $\begin{array}{l}\text { Votos } \\
\text { válidos }\end{array}$ & $\begin{array}{l}\text { Votos } \\
\text { a favor }(\%)\end{array}$ & $\begin{array}{l}\text { Votos } \\
\text { contra }(\%)\end{array}$ \\
\hline Pensionista & 804.282 & 798.565 & 91,26 & 8,51 \\
\hline Agricultores & 116.299 & 114.190 & 61,23 & 38,77 \\
\hline $\begin{array}{l}\text { Trabalhadores da } \\
\text { indústria química }\end{array}$ & 267.620 & 262.753 & 53,44 & 46,53 \\
\hline $\begin{array}{l}\text { Trabalhadores da } \\
\text { construção civil }\end{array}$ & 160.344 & 157.310 & 72,40 & 29,86 \\
\hline Metalúrgicos & 732.945 & 717.533 & 44,68 & 55,32 \\
\hline $\begin{array}{l}\text { Trabalhadores da } \\
\text { indústria têxtil }\end{array}$ & 193.007 & 188.572 & 56,97 & 43,03 \\
\hline Trabalhadores de gráficas & 58.412 & 57.166 & 56,83 & 43,17 \\
\hline $\begin{array}{l}\text { Trabalhadores de empre- } \\
\text { sas de distribuição }\end{array}$ & 156.659 & 154.005 & 64,53 & 35,47 \\
\hline $\begin{array}{l}\text { Trabalhadores de empre- } \\
\text { sas de transportes }\end{array}$ & 161.191 & 158.681 & 50,72 & 49,28 \\
\hline $\begin{array}{l}\text { Trabalhadores do setor } \\
\text { de comunicações }\end{array}$ & 139.676 & 137.785 & 53,77 & 46,23 \\
\hline Eletricitários & 105.828 & 104.231 & 61,10 & 38,90 \\
\hline $\begin{array}{l}\text { Trabalhadores de empre- } \\
\text { sas estatais }\end{array}$ & 741.686 & 730.515 & 57,46 & 42,54 \\
\hline $\begin{array}{l}\text { Bancários e trabalha- } \\
\text { dores de seguradoras }\end{array}$ & 190.573 & 186.933 & 64,90 & 35,10 \\
\hline $\begin{array}{l}\text { Pesquisadores, professo- } \\
\text { res, funcionários de esco- } \\
\text { las e universidades }\end{array}$ & 63.427 & 62.019 & 47,30 & 52,70 \\
\hline
\end{tabular}

Fonte: Nuova Rassegna Sindacale, n. 26, 10 de julho de 1995. 
1 Documento apresentado na Reunião Anual da Associação Americana de Ciência Política de 1996, no Hotel Hilton and Towers de San Francisco, de 29/08 a 1\%10/96.

2 Apesar das vantagens óbvias para os trabalhadores da indústria trazidas por essa reforma, as confederações, particularmente a CGIL, contestaram-na. Mesmo tendo sido negociada pelo governo e pelas três confederações principais, a reforma provocou protestos veementes em suas bases, induzidas pela CGIL a retirarem seu apoio. A CGIL argumentava que essa reforma só aumentava os benefícios para mineiros aposentados, e não para os mineiros ativos. Ela também organizou uma greve geral no dia 7 de março de 1968. A participação nessa greve foi tão massiva que ela foi posteriormente registrada como o início do chamado "autunno caldo" (Outono Quente). Ver Turone, 1992: 357-9.

3 Outras inovações trazidas pelas reformas do sistema de pensão no período 1968-69 incluíram o cálculo dos benefícios com base na remuneração, e não na contribuição, e a modificação na estrutura de comando do Istituto Nazionale della Previdenza Sociale (INPS), na qual os "parceiros sociais", e em particular, os sindicatos, recebiam também responsabilidades de gestão.

4 Para mais referências sobre as diferenças entre as taxas internas de reposição (IRR) para as várias categorias trabalhistas, ver Niccoli, 1991.

5 Pensões por antigüidade no posto eram uma peculiaridade italiana. Outros países europeus, tais como França e Alemanha, também permitiam formas de aposentadoria flexível para trabalhadores que tivessem sido segurados por um determinado número de anos. No entanto, tais pensões eram, em geral, pagas somente a trabalhadores com uma idade mínima (63-60, na Alemanha), ou então eram penalizadas em termos de benefícios (como na França). Para maiores referências sobre o assunto, ver OECD, 1988: 120-2.

6 Por exemplo, caso um industriário começasse a trabalhar com 15 anos (como era comum nos primeiros anos do pós-guerra), ele se aposentaria quando atingisse 50 anos de idade.

7 Para mais referências sobre as diferenças no Imposto Interno de Retorno (IRR) sobre as contribuições para pensionistas "jovens" e "adultos", ver Fornero, 1995; Padoa Schioppa Kostoris, 1995.

8 Para mais referências sobre a crise generalizada do sistema de seguro pay-as-you-go (PAYG), ver OECD, 1988.

9 Para mais referências sobre as implicações desse pacto entre gerações, ver Somaini, 1996.

${ }^{10}$ Em um sistema PAYG, o equilíbrio entre entrada e saída de capital é definido pela seguinte fórmula: $\mathrm{cWA} / \mathrm{R}=\mathrm{P}$

onde $\mathrm{c}=$ taxa de contribuição; $\mathrm{W}=$ salário médio; $\mathrm{A}=$ número de trabalhadores ativos; $\mathrm{R}=$ número de trabalhadores aposentados e $\mathrm{P}=$ pensão média.

A fórmula mostra claramente que o valor das pensões depende da proporção entre trabalhadores ativos e aposentados (por vezes definida como "grau de maturidade" do fundo de pensão). Quando essa proporção cresce, é possível aumentar os benefícios sem aumentar a taxa de contribuição, ou então reduzir a taxa de contribuição mantendo as pensões constantes. Para mais detalhes, ver Livi Bacci, 1995.

${ }^{11}$ Para mais detalhes, ver Castellino, 1990. 
12 Este conflito de interesses entre gerações na Itália foi, mais tarde, agravado por outro problema, a fragmentação interocupacional. O sistema italiano de pensões era constituído por uma pluralidade de esquemas ocupacionais, todos parecidos com o mecanismo PAYG. Tais fundos ocupacionais eram caracterizados por diferentes graus de maturidade, isto é, por diferentes proporções entre trabalhadores ativos e pensionistas. Os primeiros fundos de pensão a se estabelecerem, como o FPLD, tinham uma proporção comparativamente baixa de trabalhadores ativos, apresentando, portanto, uma estrutura passiva. Outros fundos, como os que amparavam os autônomos, eram ainda relativamente jovens, e portanto, financeiramente equilibrados. Estes fundos podiam, desta forma, impor a seus associados taxas de contribuição mais baixas que outros fundos. Era politicamente difícil transferir dinheiro de esquemas ativos para esquemas passivos, ou mesmo equalizar as taxas de contribuição. De fato, as partes envolvidas interpretavam a situação financeira de seus esquemas não (como elas deveriam) como o resultado de condições demográficas particulares, mas sim como a consequiência de capacidades gerenciais distintas. Em outras palavras, aqueles grupos trabalhistas cujos fundos de pensão estivessem ainda ativos argumentavam que eles eram capazes de gerir melhor seus fundos de pensão do que outras categorias, e recusavamse a financiar com o dinheiro deles os fundos passivos.

13 Os benefícios de pensão na Itália são calculados como um percentual do que se costuma denominar "remuneração pensionável". Até 1992, isso correspondia à média da remuneração mensal dos últimos cinco anos, para trabalhadores da indústria, e à última remuneração mensal para empregados do setor público. Este modo de determinar os benefícios de pensão levou, basicamente, a duas modalidades de distorção: 1) ele criava incentivos para a evasão de impostos e contribuições de previdência social nos primeiros anos de trabalho, já que somente os últimos contracheques seriam considerados para a determinação das pensões; 2 ) ele favorecia os trabalhadores que recebiam os maiores aumentos salariais no final de suas carreiras. Para (em parte) prevenir tais problemas, todos os projetos de reforma da década de 80 pretendiam aumentar para 10 anos o período de referência da base que determina a remuneração pensionável.

14 O projeto de reforma Donat-Cattin era particularmente interessante, porque propunha financiar os esquemas suplementares de pensão com a utilização de parte das reservas financeiras acumuladas para o pagamento de indenizações (o chamado Fondo Trattamento di Fine Rapporto ou Fondo TFR). Essa idéia foi recentemente implementada pela Reforma Treu/Dini de 1995.

15 Por exemplo, em 1990 uma nova lei modificava as pensões dos autônomos, introduzindo um sistema PAYG (que garante às primeiras gerações de pensionistas benefícios muito mais altos que as contribuições pagas) em seus fundos de pensão.

16 Tanto a presente seção quanto a próxima são baseadas em pesquisas de campo realizadas em julho de 1996.

17 O ano de 1992 foi difícil para a Itália. Primeiro, os principais partidos políticos, incluíndo do partido Democrata Cristão (DC) e o Partido Socialista (PSI) foram atingidos por uma onda de escândalos de corrupção que ficou conhecida como mani pulite (mãos limpas). Alguns deles, como o Partido Socialista, desapareceram nos meses que se seguiram. Em segundo lugar, a Máfia Siciliana lançou um ataque armado contra o estado italiano: em maio e julho, dois dos mais famosos juízes antimáfia, Giovanni Falcone e Paolo Borsellino, foram assassinados. Por último, uma séria crise financeira forçou a lira para fora do Sistema Monetário Europeu em setembro, estimulando a desvalorização massiva da moeda italiana.

18 O governo Amato aprovou uma legislação que reduzia os gastos governamentais, e aumentava a arrecadação para um total de 120 trilhões de liras em 1992 (cerca de 7,5\% do PIB). 
19 O número mínimo de anos de contribuição aumentou de 20 (15 para mulheres) para 35 - aplicando-se o mesmo limite para trabalhadores do setor privado. Deste modo, as chamadas baby pensions foram gradualmente eliminadas.

20 Tais dados pressupunham que pensões futuras seriam indexadas somente aos preços, e não aos salários. Ver Pizzuti, 1994: Tabela 7, p. 69.

21 As confederações só se opuseram a uma medida adicional que Amato pretendia introduzir: o aumento do período de contribuição necessário para pensões por antigüidade de 35 para 36 anos. Pressionado por sindicados, Amato desistiu dessa modificação adicional (ver Cazzola, 1996:55).

22 Dados baseados no valor atual das parcelas da pensão futura. Ver Banca d'Italia, 1995: Tabela 1, p. 17.

23 A Lei Orçamentária anterior preparada pelo governo Berlusconi para 1995 incluía cortes em pensões da ordem de 8.000 trilhões de liras, de 6,5 trilhões de liras nos gastos com saúde, e arrecadação por via dos chamados codoni, ou seja, a redução das violações tão comuns ao código fiscal e a divisão por distritos do pagamento das multas. Ao mesmo tempo, a nova Lei Orçamentária abolia o imposto mínimo que tinha elevado os impostos para autônomos.

24 Ver European Industrial Relations Review, 251, dezembro de 1994: 7.

25 Lamberto Dini foi Ministro do Tesouro do governo Berlusconi. Nesse cargo, ele apoiou os cortes nas pensões propostos por Berlusconi. Depois da renúncia do Primeiro-Ministro, ele liderou um gabinete composto por técnicos, ou seja, especialistas não explicitamente filiados a nenhum partido político. Seu novo Ministro do Trabalho era Tiziano Treu, um professor de direito trabalhista e especialista em relações industriais que, no final dos anos 70 , tinha defendido a necessidade da introdução de políticas neocorporativistas na Itália, a exemplo de vários países escandinavos ou norte-europeus (ver, por exemplo, Treu 1984).

26 Foi estimado que 57\% dos fundos transferidos do Tesouro para o INPS em 1992 foram utilizados para financiar medidas de assistência, tais como impostos reduzidos para companhias em áreas economicamente deprimidas (as fiscalizzazione degli oneri sociali) ou aposentadorias precoces em setores em declínio (PIzzuTI, 1994: 58). Essas separações entre seguro e assistência visavam esclarecer tanto a fonte quanto o destino dos diferentes fundos.

${ }^{27} \mathrm{O}$ novo sistema de pensão da Itália estimulava um modelo autofinanciado, mas foi mantido o sistema pay-as-you-go (PAYG). Em um modelo autofinanciado, cada trabalhador acumula (por meio de suas próprias contribuições à previdência social) um fundo de reserva que será usado para financiar os seus benefícios de pensão. Em um sistema PAYG, os trabalhadores ativos financiam os pensionistas. No sistema PAYG italiano, os benefícios eram calculados como se o sistema operasse como um modelo autofinanciado, no sentido que os benefícios eram determinados com base nas contribuições acumuladas. Teria sido impossível simplesmente mudar de um sistema PAYG para um modelo autofinanciado. Isto teria imposto uma carga muito pesada à geração ativa do momento, que iria responsabilizar-se pelo financiamento tanto dos recursos necessários ao estabelecimento de esquemas autofinanciados quanto dos recursos necessários para o pagamento das pensões dos aposentados.

28 No período de transição até a implementação total da reforma (ou seja, até o ano 2008), os trabalhadores ainda terão o direito a pensões por antigüidade, mas o número mínimo de anos para pagamento de seguro aumentará gradualmente de 35 para 40. Uma alternativa será os trabalhadores aposentarem-se após 35 anos de contribuição, caso eles tenham alcançado a idade mínima, que também crescerá gradualmente de 52 para 57 anos.

${ }^{29}$ A reforma também estendeu o seguro de pensão compulsório para grupos de trabalhadores que não estavam previamente cobertos por pensões estaduais. Esses trabalhadores 
foram designados coletivamente como lavoro parasubordinato. Essa categoria inclui uma variedade de contingentes de trabalhadores, especialmente jovens profissionais, contratados formalmente como consultores, mas que exercem de facto as mesmas tarefas que os outros empregados. A reforma Treu/Dini introduziu o seguro compulsório de pensão para esses trabalhadores também, financiado por contribuições de $10 \%$ (2/3 pagos pelo empregador, 1/3 pago pelo empregado). A reforma também introduziu pensões estaduais para trabalhadores imigrantes.

${ }^{30}$ A reforma previa uma transição gradual do novo esquema de pensão. Na verdade, foi estabelecido que a nova regulamentação seria inteiramente aplicada somente aos trabalhadores recém-contratados. Trabalhadores segurados pelos últimos 18 anos seriam sujeitos às regras anteriores (com uma exceção importante das severas regras para solicitação de pensões por antigüidade). Trabalhadores segurados por menos de 18 anos teriam suas pensões determinadas por meio de um sistema misto, que combinava as regras vigentes até 1995 e as novas regulamentações.

31 Depois de assinado, o acordo foi enviado para o Parlamento com duas vertentes contrárias de críticas, provenientes tanto da direita quanto da esquerda. O Partido da Refundação Comunista (Rifondazione Comunista) denunciava que os cortes das pensões eram muito severos, ao passo que o partido neoliberal de Berlusconi (Forza Italia) afirmava que a reforma era muito generosa e não tinha o rigor suficiente para resolver os problemas da ainda altíssima dívida pública italiana. A atitude da pósfascista Alleanza Nazionale era ambígua: de uma lado, ela por vezes unia-se às fileiras de sua aliada política Forza Italia; de outro, ela pretendia restaurar por meio de emendas legislativas muitas das cláusulas parlicularísticas que favoreciam os trabalhadores do setor público e os autônomos (duas das suas maiores bases) que a Reforma Treu/Dini havia atenuado ou eliminado.

32 Para mais detalhes sobre as dificuldades de se impor medidas de arrocho devido à fragmentação dos interesses envolvidos, ver Pierson, 1996.

33 A utilização de períodos menores de tempo produzia distorções e, às vezes, verdadeiras fraudes, no sentido de que os últimos salários (aqueles sobre os quais as pensões deveriam ser calculadas) eram em muitos casos aumentados artificialmente, de modo que o trabalhador poderia receber pensões mais altas.

${ }^{34}$ Sobre a tendência à barganha política para comprometer a coesão de sindicatos, ver Pizzorno, 1978a e 1978b. Philippe Schmitter e Wolfgang Streeck expressam o mesmo conceito referindo-se a duas lógicas conflitantes de representação: a lógica da filiação e a lógica da influência. (Ver SCHMitTer, 1989, e StREECK, 1994). De acordo com os autores, grupos de interesse em geral, e sindicatos em particular, eram comprometidos com duas empresas conflitantes. De um lado, eles precisavam satisfazer as exigências de suas bases para salvaguardar sua coesão interna (lógica da filiação). Do outro, eles precisam engajar-se em compromissos para maximizar seus próprios objetivos organizacionais (lógica da influência). Apesar das duas lógicas estarem claramente relacionadas (visto que o apoio à filiação é necessário para adquirir-se influência política e de negociação e vice-versa), a organização dos sindicatos parece visar constantemente ao alcance de um equilíbrio temporário entre essas duas forças antagônicas.

35 Ver, por exemplo, a original definição de coorporativismo de Schmitter (SCHMITTER, 1979:13). O coorporativismo pode ser definido como o sistema de representação de interesses, no qual as unidades constituintes organizam-se em um limitado número de categorias singulares, compulsórias, não-competitivas, ordenadas hierarquicamente e funcionalmente diferenciadas, reconhecidas ou licenciadas (se não criadas) pelo Estado e brindadas com um monopólio de representação deliberado, dentro de suas respectativas categorias, em troca da observação de determinados controles na seleção de líderes e na articulação de demandas e apoio (itálico do autor). 
${ }^{36} \mathrm{O}$ caráter não-democrático das organizações neocoorporativistas é talvez melhor expressado por Wolfgang Streeck: "O que é liberal no coorporativismo liberal e, possivelmente, na democracia liberal em geral é, ... a liberdade de entrar e sair, não de indivíduos com relação aos seus sindicatos, mas de associações em relação às políticas estatais e tentativas de implementação de ajustes sociais. Do ponto de vista da diferença entre autoritarismo e democracia, a liberdade de ação coletiva com relação ao Estado parece mais importante que a liberdade dos indivíduos em participar de ações coletivas com relação às suas organizações". Streeck, 1994: 11 (tradução para o inglês e itálico do autor)

${ }^{37}$ Para uma comparação entre os Movimentos Trabalhistas sueco e italiano, ver Baccaro e Locke, 1996.

${ }^{38}$ Essa experiência com a democracia dos sindicatos foi parte de um processo maior de mudança organizacional. Confrontadas com uma crise séria de representação, as confederações italianas (CGIL, CISL e UIL) tentaram um relançamento interno da democracia, institucionalizando as eleições periódicas para representantes de locais de trabalho, organizando freqüentes assembléias para discutir as agendas de negociação, e sujeitando todas as negociações à aprovação dos trabalhadores, por meio de assembléias e referendos. Para mais detalhes sobre o assunto, ver Locke e Baccaro, 1996b.

${ }^{39} \mathrm{O}$ valor médio das pensões para idade avançada administradas pelo INPS era 14 milhões de liras anuais no final de 1994 (cerca de 9 mil dólares). Esse valor nem sempre era suficiente para sustentar um trabalhador aposentado, principalmente nas grandes cidades. Porém, muitos grupos de trabalhadores, do serviço público e do setor de serviços, receberam pensões bem mais altas (ver Tabelas 2 e 3 ).

${ }^{40} \mathrm{Em}$ algumas assembléias, os trabalhadores justificavam sua exigência em manter as pensões por antigüidade, declarando que certos empregos, como, por exemplo, em lojas de tintas, reduziam a expectativa de vida em até oito anos. Ver Nuova Rassegna Sindacale, de 29 de maio de 1995:11.

${ }^{41}$ No caso especial de serviços especializados, as pensões por antigüidade constituíam uma arma poderosa de negociação com relação aos empregadores. Quando um trabalhador de serviços especializados atingia os 35 anos de contribuição, podia ameaçar aposentar-se e, desta forma, forçar o empregador a pagar-lhe melhores salários ou a oferecer melhores condições de trabalho.

42 Sobre esse tema, preparamos vários artigos, que foram publicados pela Nuova Rassegna Sindacale (a revista semanal da CGIL) de maio e junho de 1995, descrevendo as referidas assembléias e debates.

43 É por isso, por exemplo, que uma empregada, do sexo feminino, do Gruppo Financiario Tessile (uma grande empresa têxtil localizada perto de Turim) declarou durante uma assembléia realizada em sua fábrica: "Estou convencida de que a reforma tinha de ser feita, porque o dinheiro havia acabado. E eu também acredito que essa reforma pode ajudar-nos a salvar algum dinheirinho para as pensões de nossos filhos. Nuova Rassegna Sindacale, 29 de maio de 1995:12.

44 Entrevistado pela Nuova Rassegna Sindacale, um operário da fábrica Asea Brown Boveri (Sesto San Giovanni) declarou: "Isso é como uma corrida. Quando você finalmente chega à linha de chegada, exausto, você vê uma placa que diz: 'Desculpe, nós nos enganamos. Você ainda tem de correr mais dez quilômetros'”. Nuova Rassegna Sindacale, 5 de julho de 1995: 15 (tradução para o inglês do autor).

45 No Sul, industriários de meia-idade estavam muito menos preocupados com as pensões por antigüidade que seus colegas do Norte, visto que a falta de empregos estáveis tornava muito difícil para qualquer trabalhador acumular 35 anos de contribuição. Ver, por exemplo, os comentários de um operário da fábrica da Fiat em Termini Imerese 
(perto de Palermo): "Como podemos conseguir atingir 35 anos de contribuição aqui na Sicília? Não há empregos aqui. (Cca travagghiu un ci nne' em dialeto siciliano). Nuova Rassegna Sindacale, 8 de maio de 1995: 24 (tradução para o inglês do autor).

${ }^{46} \mathrm{~A}$ convicção de que o debate interno era preferível à deserção foi claramente expressa por um membro do Consiglio di Fabbrica (Conselho Trabalhista) da Officine Savigliana (uma oficina mecânica próxima a Turim), entrevistado após o Consiglio di Fabrica tinha rejeitado o acordo sobre o sistema de pensões: "Para nós, o mais difícil de engolir é o aumento na idade mínima para aposentadoria. Ainda assim,... creio que nós devemos lutar dentro do sindicato para mudar essas provisões que consideramos inaceitáveis. Para podermos fazê-lo. Nós devemos ser e continuar membros do sindicato". Nuova Rassegna Sindacale, 5 de julho de 1995: 16 (tradução para o inglês do autor).

${ }^{47}$ Essas 49 mil estações eleitorais eram aproximadamente metade das que foram instaladas pelo Ministério do Interior na época das eleições legislativas. Ver Carlo Ghezzi, "Le lezioni del voto". Nuova Rassegna Sindacale, 10 de julho de 1995:III.

46 Essas 49 mil estações eleitorais eram aproximadamente metade das que foram instaladas pelo Ministério do Interior na época das eleições legislativas. Ver Carlo Ghezzi, "Le lezioni del voto". Nuova Rassegna Sindacale, 10 de julho de 1995: III. 


\section{Reforma do setor público e participação sindical: o caso do sistema de pensão italiano \\ Lucio Baccaro e Richard M. Locke}

O paper estuda o caso da recente reforma da Previdência na Itália, ilustrando a possibilidade de uma participação positiva dos sindicatos — tradicionalmente contrários às reformas — no processo de transformação do setor público.

Após uma revisão do sistema previdenciário italiano, altamente fragmentado e particularista na opinião dos autores, e o apontamento de suas principais deficiências, o estudo concentra-se na análise de três propostas de reforma ligadas aos governos de Amato (1992-93), Berlusconi (1994) e Dini (1995), respectivamente. O texto aborda tanto as propostas concretas de mudança, trazendo contribuições sobre uma variedade considerável de medidas, seu impacto e aceitação sociais e por categoria, como os objetivos visados e o processo político relacionado à sua discussão e tramitação. Uma preocupação constante dos autores é a correlação entre a postura e a participação dos sindicatos em matéria de reforma previdenciária, por um lado, e o avanço das propostas governamentais, por outro. Segundo o estudo, a ampla participação da força sindical na negociação do projeto de reforma previdenciária do governo Dini representou um fator decisivo para sua aprovação e implementação bem-sucedidas.

Ao mesmo tempo, a deliberação democrática para conciliação de preferências e interesses (múltiplos no caso de assuntos norteados pela dicotomia bem comum/interesse particular) — objeto da última sessão do estudo — é vista como uma forma de ampliar a participação sindical além das lideranças, passando a incluir os rank-and-file trabalhadores, um procedimento que traz, igualmente, a força de uma decisão majoritária.

A análise da reforma da Previdência italiana é ilustrada no paper com tabelas que trazem e comparam dados referentes à contribuição previdenciária, às categorias de beneficiados e às diferentes propostas de reforma formuladas por sucessivos governos italianos.

\section{La reforma del sector público y la participación de los sindicatos: el caso de la reforma de la Seguridad Social en Itália}

\section{Lucio Baccaro y Richard M. Locke}

El artículo estudia el caso de la reciente reforma de la Seguridad Social en Itália, al ilustrar la posibilidad de una participación positiva de los sindicatos - tradicionalmente contrarios a las reformas - en el proceso de transformación del sector público.

Tras la revisión del sistema de Seguridad Social italiano, altamente fragmentado y particularista según los autores, y el apuntameiento de sus principales deficiencias, el estudio se concentra en el análisis de tres propuestas de reforma ligadas a los gobiernos de Amato (1992-93), Berlusconi (1994) y Dini (1995) respectivamente. El texto aborda tanto las propuestas concretas de cambio, aportando contribuciones sobre una variedad considerable de medidas, su impacto y aceptación sociales y por categoria, como los objetivos visados y el proceso político relacionado a su discusión y tramitación. Una preocupación constante por parte de los autores es la correlación entre el comportamiento y la participación de los sindicatos respecto a la matéria de la reforma 
de la Seguridad Social, por un lado, y el avance de las propuestas gubernamentales, por otro lado. Según el estudio, la amplia participación de la fuerza sindical en la negociación del proyecto de reforma de Seguridad Social del gobierno de Dini representó un factor decisivo para el buen éxito de su aprobación e implementación.

Mientras tanto, la deliberación democrática para la conciliación de preferencias e intereses (múltiplos en el caso de asuntos orientados por la dicotomía bien común/interés particular) - objeto de la última sesión del estudo - es considerada como una forma de ampliar la participación sindical además de los liderazgos, pasando a incluir los obreros rank-and-file, um procedimiento que aporta, igualmente, la fuerza de una decisión mayoritaria.

El análisis de la reforma de la Seguridad Social italiana es ilustrada en el artículo con tablas que aportan y comparan datos referentes a la contribución de la Seguridad Social, a las categorias de beneficiados y a las diferentes propuestas de reforma formuladas por sucesivos gobiernos italianos.

The reform of the public sector and the union participation: the case of the pension reform in ltaly

Lucio Baccaro and Richard M. Locke

The paper analyzes the case of the ltalian pension reform recently carried out, as an example of a positive participation of labour unions - traditionally opposite to reforms - in the process of public sector reform.

After reviewing the ltalian pension fund system - highly fragmented and particularistic, according to the authors' view - and showing its main deficiencies, the paper focus on the analysis of three reform proposals, designed by the of Amato (1 99293), Berlusconi (1994) and Dini (1995) Governments, respectively. The text refers to concrete reform proposals, that brought a considerable variety of measures, their social impact and acceptance, sorted by labour category, as well as the aimed goals and the political process related to its discussion and implementation procedure. The authors are continually concerned with the correlation between unions' attitude and participation regarding the pension reform, on one hand, and the advancement of governmental proposals, on the other. According to this study, the broad participation of unions in the negotiation of Dini's proposed pension reform was a decisive factor for its successful approval and implementation.

Simultaneously, the democratic debate aimed at conciliating preferences and interests (diverse, in which refers to the dicotomy common good/private interest rest) - object of the last part of the study — is seen as a way of ensuring union participation beyond its leadership, including rank-and-file workers, a procedure that equally brings the strength of a majority decision.

The analysis of the ltalian pension reform is illustrated in the paper by tables that provide and compare data regarding pension contributions, beneficiary categories and different reform proposals, designed by successive italian governments. 
A Revista do Serviço Público é uma publicação da Escola Nacional de Administração Pública — ENAP, voltada para a divulgação e debate de temas relacionados ao Estado, à Administração Pública e à gestão governamental. Procurando o aprimoramento permanente da revista, tanto no seu conteúdo quanto na apresentação gráfica, pedimos aos nossos colaboradores a observação das normas abaixo descritas.

\section{Normas para os colaboradores}

1. Os artigos, sempre inéditos no Brasil, devem conter em torno de 25 laudas de 20 linhas de 70 toques.

2. Os originais devem ser encaminhados ao editor, em disquete, em programa de uso universal, com uma cópia impressa. Usar apenas as formatações-padrão.

3. Cada artigo deve vir acompanhado de um resumo analítico em português, espanhol e inglês, de cerca de 150 palavras, que permita uma visão global e antecipada do assunto tratado.

4. Na primeira página do artigo, deve constar informação sobre formação e vinculação institucional do autor (em até duas linhas).

5. Notas, referências e bibliografia devem vir ao final do artigo, e não ao pé da página. Notas e referências, sendo o caso, devem vir devidamente numeradas.

6. Além de artigos, a revista receberá comunicações, notas informativas, notícias e relatórios conclusivos de pesquisas em desenvolvimento, com até 15 laudas. Resenhas de livros, em torno de 4 laudas, devem conter uma apresentação sucinta da obra e eventuais comentários que situem o leitor na discussão.

7. Os trabalhos que se adequarem à linha temática da revista serão apreciados pelo conselho editorial, que decidirá sobre a publicação com base em pareceres de consultores ad hoc.

8. Os originais enviados à Revista do Serviço Público não serão devolvidos. A revista comprometese a informar os autores sobre a publicação ou não de seus trabalhos.

\section{Convite a resenhadores}

A Revista do Serviço Público convida todos os interessados em remeter resenhas de trabalhos publicados no Brasil e no exterior sobre Estado, Administração Pública e gestão governamental.

As resenhas devem ser originais e não exceder a cinco laudas datilografadas em espaço duplo com 20 linhas de 70 toques, e devem apresentar de modo sucinto a obra, com comentários que situem o leitor na discussão apresentada.

As resenhas devem ser enviadas em português, sem notas de rodapé, contendo o título completo e subtítulo do livro, nome completo do autor, local de publicação, editora e ano de publicação, bem como uma breve informação sobre a formação e vinculação institucional do resenhador (em até duas linhas), acompanhadas do respectivo disquete.

\section{Nota aos editores}

Pedimos encaminhar à Revista do Serviço Público exemplares de livros publicados, a fim de serem resenhados. Os resenhadores interessados receberão cópias dos livros enviados. 